\title{
Helping People Through Use of Theories
}

\author{
Robert J. Gregory \\ School of Psychology, Massey University, Palmerston North, New Zealand \\ E-Mail: R.J.Gregory@massey.ac.nz
}

KEY WORDS: Helping; theories; reflection; analysis.

ABSTRACT Many human service and vocational guidance practitioners are so busy they have little time to reflect on their work with clients, and on the clients and their situations. Yet reflection and study and analysis is more important now than ever to be helpful, especially in such arenas as counseling, vocational guidance and job placement. A variety of theories can be used as reflective lenses, to enable practitioners to understand clients and behavior, and then intervene appropriately. Several theories are briefly presented as suggestive examples. The author recommends use of a list or collection of theoretical materials, adjacent to their workplace settings, for guidance and human service professionals and paraprofessionals.

\section{HELPING PEOPLE THROUGH USE OF THEORIES}

Many professionals deal with multitudes of patients, clients and the general public and end their day with few opportunities and even less energy to analyze their interactions and the situations of people seeking help. In the frenzy of modern times, interviewing, counseling, gathering and sharing information, assessing or testing, and otherwise interacting can become trivialized, or production-line oriented, or even worse, activity based for activities sake. Reflection, analysis, critical analysis, thoughtful and insightful study by the helper of the client, their environment or life situation, and the interactive process, may be neglected.

At the same time, effective and efficient interaction has never been more important. Accurate, detailed, and deep levels of critical analysis of both the processes of interaction and the substance and context being handled are essential. Otherwise, appropriate interventions made in the lives and situations of people cannot take place. Taking opportunities to reflect on people and interactions through use of cue cards, lists, abstracts, or books on social science theories, can elevate insight and understanding and serve to focus subsequent action.

The skilled helper does "not help others in order to satisfy their own needs," (Egan, 1982, p. 28) for they have reflected and do reflect on their own lives and roles sufficiently to remain "grounded" and secure, hopefully. However, whether professional, para-professional, or one of the "new human service generalists" (Dugger, 1980 , p. 8-14), helpers today engage in a wide variety of activities to assist others: brokering, advocating, mobilizing, changing systems, solving problems, building skills, consulting, teaching, remediating, care giving, case managing, milieu managing, handling data, and operating programs, as examples (Mehr, 1983, see pages 22-23). And in a busy daily schedule of activities, few people do take time to reflect, review, analyze, and study either process or people.

The thesis of this article is that reflection and analysis is not only valuable, but indeed, is essential. Further, sound reflection and analysis stems from acquaintance with and use of theoretical perspectives, and especially, active use of multiple perspectives from the many available theoretical frameworks, on an on-going basis. To this end, a series of potentially useful theoretical frameworks, for reflection and analysis, are listed below.

These psychological or sociological theories can together provide a resource, particularly in such realms as vocational guidance and job placement efforts. Theories can help professionals and paraprofessionals match seekers and jobs, for example. This article focuses on theoretical frameworks related to vocational counseling and job seeking, and suggests ways about how to use these theories to help applicants get the right job. Maintaining a list of theories readily accessible enables helpers to make better use of time otherwise unoccupied to reflect and analyze.

\section{BACKGROUND}

Career planners who have experientially gained wisdom about helping people with job 
seeking, and/or who have an acquaintance with and education in the social sciences, can analyze and theorize on the guidance and placement process to great advantage. By mentally tracing the steps through which people obtain jobs, that is, by using the lens provided by various theoretical frameworks, career development, vocational guidance, and rehabilitation professionals can conceptualize and then steer or guide the pathways by which people gain their first job, a new job, or change jobs.

\section{ADVANTAGES OF THEORY}

Theories offer a scientific way of explaining, understanding, predicting and controlling. Many processes take place in every effort to match people with jobs. Examination of job seeking, matching, and vocational placement through use of a theory constitutes a step in the process of scientific understanding. This can lead from explanation, through understanding, to prediction and greater control of placement. With capricious, random phenomena occurring, placement efforts have little impact. With even slight deviation from randomness, placement workers have a far better chance of helping clients gain a job.

\section{THEORIES-PSYCHOLOGICAL}

1. Freudian theory (Rickman, 1953) is a rich source of ideas, including the unconscious, the three aspects of the personality (id, ego, and superego), and repression. As an example, if a job seeker fantasizes about work desired, then compares resulting dreams with reality and/or expectations held by others, personality divisions as formulated by Freud (id, ego, and super-ego) might become clearer. The expectations an individual has about the world of work may be deeply affected by subconscious factors in the personality, and the alert career planner should be aware of any great disparities. This can lead towards insights and a more appropriate career.

2. Developmental psychology (Erikson, 1982) focuses on growth, and on life stages. The life cycle can be and is relevant to both individuals and to organizations. A new organization is exciting, full of potential, dynamic, and relatively unstructured, so that generalists fit in well. An older organization offers sound structure, with steady routines that have been worked out and yet, it may continue to offer opportunity to specialize. The idea of entry level jobs, career development, work hardening, and emergence of "work personality", and degree of specialization, all represent aspects of the developmental viewpoint.

3. Reinforcement theories (Skinner, 1969) offer many ideas about why individuals perform as they do. The process by which a client seeks employment is akin to the same processes by which rats run mazes. Meaningful work, remuneration packages, and money represent tangible rewards. Rewards might serve as driving motivation. Rewards might be achieved quickly by those who figure out and master strategies to gain higher level positions. The career planner can help clients see and use the relationships between work and reward.

4. Learned helplessness (Garber and Seligman, 1980) is a fascinating theory that followers claim some people learn or are taught, and they then act in passive ways. Other people then provide what is needed - acting helpless begets help and leadership from nearby others. Although such behavior may be effective for some individuals in some settings, it may prove to be a disadvantage for a person in other settings and times. Interventions by a career planner may succeed in breaking patterns of learned helplessness or at least help the individual to be more aware of his or her actions. On the other hand, of course, a client may become dependent upon the career planner in a continuing helplessness mode.

5. Bonding (Byrne, 1971; Sluckin, et al., 1983; Bowlby, 1973) is a process by which a mother-infant, a husband-wife, or other pairs and groups establish mutual dependence. The bond, on physical, psychological, emotional, and/or social levels, is a longterm positive attraction. Bonding in people is similar to the process by which a company, organization, or work team forms ties with a recruit who becomes an employee. The growth and nurture of a long-term bond can determine the tenure of a position, and therefore is an important aspect of career counseling. Those who do not bond may 
have had previous negative experiences in life, and counseling can reveal strategies for intervention.

6. Need achievement (McClelland, 1976) has been studied and applied in many situations. A common goal for job-seekers is to locate meaningful work. Job-seeking is a way to satisfy these needs. Similarly, organizations that are achievement oriented have achievement needs - goals, production standards, survival, and profit, for example. Matching individuals with organizations appropriately can take achievement needs of both into account. A placement person may be highly motivated by the task, and keeping a weekly tally of successes may be a useful way to monitor achievements.

7. Hierarchies of motivational levels such as those formulated by Abraham Maslow (1954) fit many different individuals and can also be applied to particular companies and even types of careers. Varying levels of motivation, such as physical needs, safety, receiving love, esteem and power, and giving affection, can explain, and perhaps predict a matching and potential tenure of the relationship of an employee and an employer.

8. Ecological theory (Odum, 1983; Hershenson, 1998) examines environments, and how people fit the various sociological niches that are available in a community. The world of work includes many niches, where specialized talents, unusual abilities, different personalities and so on may have a place. The notion of succession and competition for time and space in an ecological arrangement can also be applied to the work place and to those who compete for a limited number of jobs.

\section{Sociological Theories}

8. General systems theory (Berrien, 1968; Buckley, 1967) originated from early work by von Bertalanffy (1933). A system is a set of elements, in exchange, bounded by a permeable or impermeable boundary, and often possessing direction, or goal orientation. Systems ideas could be applied to a corporate entity, wherein growth necessitates expansion of the number of people or elements employed. The person- nel office (or boundary mediator) must be contacted, and when hired, new employees must be socialized to maintain working relationships (or exchanges) that are appropriate with other people (elements). They must be able to meet output or production standards, and not be disruptive of internal operations.

9. Exchange theory (Davis, 1992) includes transactions between people and organizations. The exchange of gifts, money, materials, or other tangible and intangible items has been extensively studied. The relationship of a worker performing some task, in return for payment - a weekly wage - constitutes an exchange. Further, the idea of exchanges could be applied to the complex relationship between a placement person, a client, and an employer.

10. Territoriality (Ardrey, 1967; Klopfer, 1969) concerns the space appropriated by an individual for personal (or group) use. Arising from studies of how individuals or groups of animals use and control geographical space, territoriality could be applied to the use and control of space by workers, and their resistance to outsiders entering such space. A new worker, for example, might be harassed or enter a dominance struggle, or be subject to pranks, by those who have worked in an organization for a long time. The placement person's attempts to enter various organizations for the purpose of obtaining employment for his/her client might be affected by this idea of territoriality.

11. A role is patterned behavior of an individual such that it (the behavior) meets the needs and expectations of others. According to Merton (1968) and other theorists, the notion of role carries status, rights and responsibilities. The holder of a role is a person, but the person is more than just a role. Role theory can apply to job-seekers, and whether their role is conducted successfully. If the job seeker does not meet the expectations of others, conduct in the role category is deficient and corrections or changes may be needed.

12. Probability (Whittle, 1992; Karr, 1993) is a statistical term that concerns the likelihood that an event will occur. Precursors can be identified so that one can predict that if 
certain conditions are present, then the likelihood that particular actions will follow can be specified. As an example, probability, with appropriate data, can be used to point out that if one is 18 years, Black, and female, then the likelihood of being employed is ( $\mathrm{x}$ ), whereas if one is 30 years of age, white, and male, then the chances of being employed is $(\mathrm{y})$. This could be useful in understanding labor market information, opportunities for various individuals, and might be also applied to methods of job-seeking. For example, one use might be to identify significant steps in the job search. What is the probability of a successful job interview if the application forms are clearly and correctly completed as compared with those that are not? If the placement person can calculate the probability of an applicant's obtaining a job through taking various courses of action, the most relevant pathways can be identified and used.

\section{Use of Theories}

Using a list of theoretical constructs in the career counseling, job seeking and placement process is of definite value to researchers, practitioners, and ultimately, to clients who seek jobs. A simple listing of theories offers a way for vocational counselors and placement personnel, for example, to reflect on and analyze the information offered by job seekers in and about their various situations. The astute counselor or placement person needs and wants to understand and predict outcomes. Theoretical frameworks serve as lens by which they can study and analyze, and then influence the success of active efforts. By reviewing and understanding theoretical constructs, a counselor can examine and explore, reflect and study the complexities of job seeking and placement behavior. In addition, as business and industry openings are identified and examined, theories can again offer ways to understand the requirements of workers on such jobs. Such understanding can yield better results.

\section{CONCLUSION}

A vigorous, active interest in the mysteries of the career development and placement process is needed. The daily use of one or more, and preferably multiple theories, taken from psychology, sociology, and other nearby academic disciplines offers career planners, vocational guidance and placement personnel, researchers, and clients an opportunity to better understand and thereby predict, some of the phenomena of job seeking, placement, work, and careers. Making explicit some aspects of job seeking and placement which are generally left implicit or which are not considered, by using theories can result in new insights. Theories can and do increase ideas and action in the placement field.

\section{REFERENCES}

Ardry, Robert. 1967. The Territorial Imperative: A Personal Inquiry into the Animal Origins of Property and Nations, London: Collins.

Berrien, Frederick K. 1968. General and Social Systems, New Brunswick, NJ: Rutgers University Press.

Bertalanffy, Ludwig von. 1933. Modern Theories of Development: An Introduction to Theoretical Biology, London: Oxford University Press.

Bowlby, J. 1973. Attachment and Loss, Volume 2, Separation, Anxiety and Anger, New York: Basic Books.

Buckley, Walter F. 1967. Sociology and Modern Systems Theory, Englewood Cliffs, NJ: Prentice Hall.

Byrne, Donn. 1971. The Attraction Paradigm, New York: Academic Press.

Davis, John 1992. Exchange, Buckingham: Open University Press.

Dugger, James G. 1980. The New Professional: An Introduction for the Human Services Worker, Monterey, CA: Brooks/Cole Publishing Company.

Egan, Gerard, 1982. The Skilled Helper: Model, Skills, and Methods for Effective Helping, Monterey, CA: Brooks/Cole Publishing Company.

Erikson, Erik H. 1982. Major Stages in Psychosocial Development, New York: W. W. Norton.

Garber, Judy and Martin E. P. Seligman (Eds) 1980. Human Helplessness: Theory and Applications, New York: Academic Press.

Hershenson, David B. 1998. "Systemic, ecological model for rehabilitation counseling", Rehabilitation Counseling Bulletin, 42, 1, 40-50.

Karr, A. F. 1993. Probability, New York: Springer.

Klopfer, Peter H. 1969. Habitats and Territories: A Study of the use of Space by Animals, New York: Basic Books.

Maslow, Abraham H. 1954. Motivation and Personality, New York: Harper.

McClelland, David C. 1976. The Achievement Motive, New York: Irvington Publishers.

Mehr, Joseph. 1983. Human Services: Concepts and Intervention Strategies, Boston: Allyn and Bacon, Inc.

Merton, Robert K. 1968. Social Theory and Social Structure, New York: Free Press. 
Odum, Eugene P. 1983. Basic Ecology, Philadelphia: Saunders College Pub.

Rickman, John (ed.) 1953. A General Selection from the Works of Sigmund Freud, London: Hogarth Press.

Skinner, B. F. 1969. Contingencies of Reinforcement:
A Theoretical Analysis, New York: AppletonCentury-Crofts.

Sluckin, Wladyslaw, Martin Herbert and Alice Sluckin. 1983. Maternal Bonding, Oxford: Blackwell.

Whittle, Peter. 1992. Probability Via Expectation, New York: Springer-Verlag. 